\title{
Teacher Professional Development in Outdoor and Open Learning Environments: A Research Based Model
}

\author{
Hannu Salmi*, Arja Kaasinen, Liisa Suomela \\ Department of Teacher Education, University of Helsinki, Helsinki, Finland \\ Email: "hannu.salmi@helsinki.fi
}

Received 8 May 2016; accepted 4 July 2016; published 8 July 2016

Copyright (C) 2016 by authors and Scientific Research Publishing Inc.

This work is licensed under the Creative Commons Attribution International License (CC BY).

http://creativecommons.org/licenses/by/4.0/

(c) (i) Open Access

\section{Abstract}

The trend of utilising open learning environments and informal learning sources has a clear link to outdoor education, which bridges the gap between formal education and informal learning. According to the findings related to informal learning and its relevance to early professional development, the crucial era seems to be the first 3 years as an inexperienced teacher. Despite the long history, outdoor education needs new research methods. In Finland, the new National Curriculum 2016 underlines teaching of this "phenomenon" besides the traditional subject orientated teaching. This challenges teacher professional development at all its levels. In this study, an outdoor education course for teachers and teacher trainees in Finland is evaluated using the theory and research tool of New Educational Models or Paradigms (NEMP). The main research question is to test this new research model: is it suitable when evaluating outdoor education?

\section{Keywords}

Informal Learning, Outdoor Education, Out-of-School Education, New Educational Models or Paradigms, Science Centre Pedagogy

\section{Introduction}

Learning and education can be defined both narrowly and broadly: they can occur either unconsciously or formally. Learning from informal sources and in an out-of-school environment has been found to be effective and motivating. Two classical books describing this phenomenon are Deschooling Society by Ivan Illich (1971) and The Unschooled Mind by Howard Gardner (1991).

\footnotetext{
${ }^{*}$ Corresponding author.
}

How to cite this paper: Salmi, H., Kaasinen, A., \& Suomela, L. (2016). Teacher Professional Development in Outdoor and Open Learning Environments: A Research Based Model. Creative Education, 7, 1392-1403. 
The methods of informal learning have traditionally been used in, for example, the teaching of biology (Falk, 1982; Goldschimdt, \& Bogner, 2015), geography learning (Rennie, Feher, Dirking, \& Falk, 2003), science education (Braund \& Reiss, 2004), museology solutions (Melton, 1935), mathematics (Fenyvesi, Koskimaa, \& Lavicza 2015; Salmi, Vainikainen, \& Thuneberg, 2015) and art education (Newsom \& Silver, 1978). The first essential research concerning informal education was clearly related to biology and field education (Falk, 1982; Bitgood, 1988). Such results have since been multiplied in the literature (Braund \& Reiss, 2007; Sturm \& Bogner, 2010; Tran, 2011). To advance public understanding of science, new forms of education were actively sought (Crane, Nicholson, Chen, \& Bitgood, 1994; Rennie, Feher, Dirking, \& Falk, 2003; Holbrook \& Rannikmae, 2009; Frantz-Pittner, Grabner \& Bachmann, 2011; Salmi, 2003; Salmi, Thuneberg, \& Vainikainen 2015). Learning does not take place only in the actual world of school but in the presented world of nature, parks, yards, science centres, gardens and the media, as well as through the virtual worlds of the internet and social media (Braund \& Reiss, 2007). Despite this development, there has been less theoretical or empirical research in the informal sector (Osborne \& Dillon, 2008). Recently, informal learning has become a more accepted part of science education (Fenichel \& Scheinburger, 2010).

The terminology of informal education is variable due to, on the one hand, the slight difficulties caused by differences in school systems and, on the other, some translation problems. However, it was well defined in the UNESCO report Learning to Be-The Faure Report in 1968.

The recent boom in informal learning has not changed the view at the terminological level. However, out-ofschool education is yet another essential term. It means education that happens during school time and according to the curriculum but uses settings and institutes other than the physical school building (Figure 1).

Out-of-school education is also a term included in school legislation in several countries. Out-of-school education often uses informal education sources for formal education. It forms a pedagogical link between formal education and informal learning (Salmi, 1993; Rennie et al., 2003; Braund \& Reiss, 2007; Rennie, 2014; Salmi, Thuneberg, \& Vainikainen, 2015). Outdoor education is one form of out-of-school education and will be looked at next.

Outdoor education is an educational method that is widely used all over the world. However, the concept outdoor education has many meanings (Rickinson, Dillon, Teamey, Morris, Choi, Sanders, \& Benefield, 2004; Bilton, 2010). In some countries, the term "outdoor education" is nearly a synonym for "environmental education" (Neal \& Palmer, 1990). Through emphasising the role of experience and emotion it has been connected with adventure education and camping (D’Amato \& Krasny, 2011). Outdoor education is often used to teach biology and geography, but it can be used as an integrative element in other school subjects as well (Catling, 1998; Richardson, 1998; Job, 1999; Lambert \& Balderstone, 2010). In addition, it is well known that in biology there are plenty of themes that are easier to understand and learn in nature than in the classroom (Barker, Slingsby, \& Tilling, 2002; Falk, 2005).

Limited connections to nature during childhood may influence children and their environmental behaviour (Özden, 2008; Larson, Green, \& Castleberry, 2009). The environment, outdoor space and children's age, as well as curriculums and teachers' views influence how outdoor learning and teaching are carried out (Rickinson et al., 2004). For example, technological developments (mobile phones, social media, e-tagging; see

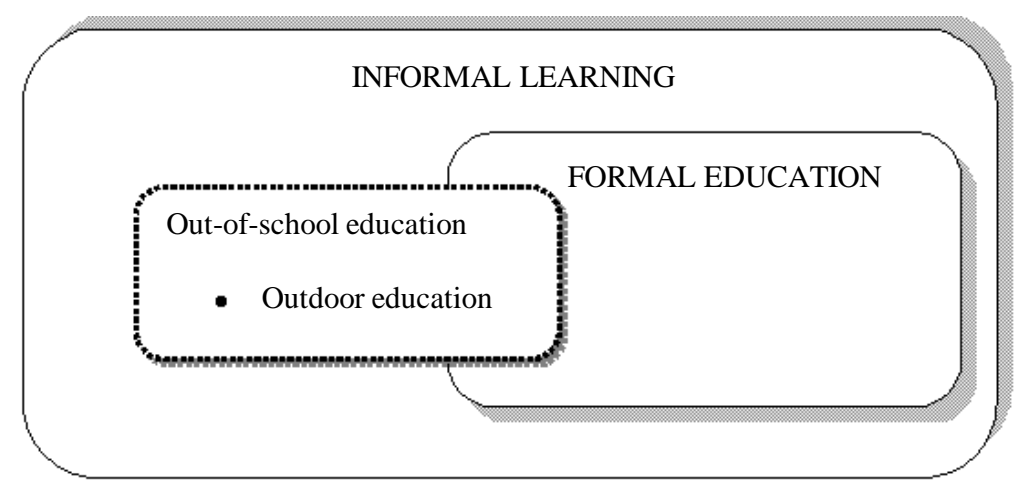

Figure 1. Out-of-school education as a link between informal learning and formal education. 
www.luontoportti.com) offer new opportunities to organize outdoor education. However, the content has to stay in focus (Baram-Tsabari \& Segev, 2009).

Outdoor education can help students learn and understand biology. In addition, it also helps in developing their affective and motoric skills (Barker, Slingsby, \& Tilling, 2002; Dillon et al., 2006; Gafoor \& Narayan, 2012). The meta-analysis carried out by Dillon et al. (2006) examined more than 150 research reports related to outdoor education between 1993 and 2003. As a summary, they conclude that there is abundant evidence of the effectiveness of outdoor education. Outdoor education has been found to be more effective in developing cognitive skills than classroom education (Eaton, 1998). Touching, feeling, smelling or interacting in some other way with wildlife is an effective way of learning (Ballantyne \& Packer, 2002). Outdoor education can stimulate students on the emotional level to understand the link to and their effect on the environment (Bogner, 1998; Bogner \& Wiseman, 2004; Erdogan, Erentay, Barss, \& Nechita, 2008; Cavas, 2011; Larson, Green, \& Castleberry, 2011). Fieldwork has been shown to motivate students (Yerkes \& Haras, 1997; Zoldasova \& Prokop, 2006; Sturm \& Bogner, 2010). Motivation helps students to not only learn but also to remember and recall the content of biology (Dierking \& Falk, 1997). It is often forgotten that teachers' motivation and confidence in teaching science subjects are also important (Deci \& Ryan, 2007; Thuneberg, 2007; Tal, 2001; Jarvis \& Pell, 2004; Braund \& Reiss, 2006; Goldschmidt \& Bogner, 2015).

One of the main benefits of outdoor education and fieldwork is that they guide and encourage pupils to do observations. It is also a very good way of raising environmental awareness of pupils, because many researchers have documented the concern of young people's diminishing relationships with and awareness of nature (Ahtee, Suomela, Juuti, Lampiselkä, \& Lavonen, 2009; Niklasson \& Sandberg, 2010; Larson, Green \& Castleberry, 2011).

This study is performed in Finland. The Finnish national core curriculum states that, "The contents of, and approaches used in environmental and natural studies are chosen... [in such a way] that studies can also be done as fieldwork" (National Board of Education, 2004: p. 170). Traditionally, outdoor activities have been a part of the Finnish school system in some forms or another for almost as long as schools have existed (i.e., since the cathedral school system of the 1200s students have collected medicinal plants). The teaching of biology in the compulsory comprehensive school started only in 1921. Collecting herbarium specimens has been a persistent educational tradition for centuries. However, the tradition vanished from the National Curriculum in 1969 but is gradually coming back, especially as part of outdoor education in biology. In Finland, the renewed National Curriculum 2016 underlines teaching of the "phenomenon" besides the traditional subject orientated way of arranging the school schema. This has not been systematically prepared at the teacher education or the further professional development of teachers levels. Outdoor education has strong potential in this type of pedagogical approach.

In this study, outdoor education is understood and implemented as education that includes environmental education, biology and geography (Luehmann \& Markowitz, 2007; Tran, 2011; Kaasinen \& Suomela, 2012). We describe one outdoor education course where Finnish teacher trainees learned the didactics of biology in the sub-urban environments of the schoolyard, the park, the field, the stream, the forest and the trees.

\section{Methods}

\subsection{Participants}

In total, 194 second-year primary teacher trainees participated in this research in Finland. Altogether, 164 female and 30 male students completed the questionnaire. In Finland, primary school teachers teach classes 1 to 6 (children from 7 to 12 years old). Primary school teacher trainees complete a masters-level degree in education (300 ETCS). Student teachers have a compulsory minor subject called multi-disciplinary studies (60 ETCS), and the basic biology course is 3 ETCS.

\subsection{Educational Programme}

Outdoor education is included in the basic course of biology didactics in the University of Helsinki. The course includes both lectures and workshops. In the first lecture students have an exercise which introduces them to the basics of the didactics of biology through some teaching subject; for example, how to motivate pupils to learn about plants. After the lecture they participate in workshops about humans and health, perform laboratory exercises focusing on biology and species recognition and take part in outdoor education and fieldwork. 
During the outdoor education workshop students go out for 3 hours. The workshop is held near the school, which is located in the middle of a very diverse natural environment with fields, water bodies and a forest easily available. Outdoor education includes abundant practical exercises. These exercises have been chosen to give ideas and to encourage and motivate students to teach biology outside of the classroom. On this course, they acquire tools, methods and concrete hands-on activities that can be used when teaching pupils. One hour is used for performing activities in the forest, and for the rest of the time students perform exercises with water, insects and plants. Authentic learning is the key approach (Braund \& Reiss, 2006), so real plants, butterflies or spiders are preferred instead of a picture from a school book. The course awakens thoughts in the teacher trainees about the role of outdoor education, how outdoor education can change learning environments and what innovative learning approaches could be like.

\subsection{Objectives}

The context is affected strongly by the whole learning process. Even the term professional development (PD) is defined differently depending on the context in which it is delivered (Guskey, 2002). Our study aims to further analyze the findings of Lauer, Christopher, Firpo-Triplett, \& Buchting (2014) that are related in the meta-data of 292 studies to the impact of short-term professional development. One of the main outcomes of the meta-data review (Lauer et al., 2014) demonstrates that short-term PD efforts with effective design features can result in positive participant outcomes.

The focus of our research is in the context of bridging between formal education and informal learning by professional development. Recent results (Lom \& Sullenger, 2010) encourage the use and research of informal settings in teacher professional development. This matters especially in early professional development as the results from the UK (Turner, 2006) indicated. According to these findings related to informal learning and its relevance to early professional developments, the crucial era seems to be the first 3 years as an inexperienced teacher. Our article presents a similar process in the shift of teacher studies in the university as a teacher student in Finland. As a special case of informal learning, the relevance of outdoor education is examined. In this sense, this article tries to bring new evidence to the on-going discussion related to critical educative practice (Dye, Herrington, Hughes, Kendall, Lacey \& Smith, 2010).

The long tradition of teaching biology via field education has received a new renaissance, and the popularity of outdoor education has been growing in different types of educational systems. One of the reasons for this is the global environmental issues that have increased the value of outdoor education among young people in particular (Chawla \& Flanders, 2007). These trends underline the importance of ensuring that the capacity to use outdoor education in an effective way is included in the education of teacher trainees as well as in the further professional development and in-service training for teachers.

In this research, the impact of outdoor pedagogy was investigated using a tool known as New Educational Models or Paradigms (NEMP). This tool was originally developed for ICT-education research purposes but has been successfully applied in several educational contexts (Salmi, 2011; Salmi, Kaasinen, \& Kallunki, 2012). In this study, the modified version is utilised to gather feedback from teachers and teacher trainees. The main aim of this research was to find more evidence to support earlier findings: 1) the distinctive role ("Identity") of outdoor education, 2) changes in the learning environments as a consequence of outdoor education, and 3) the innovative approach behind the successful administration of outdoor education.

\subsection{The Evaluation Tool: Measuring the Role of Outdoor Education (OE) Pedagogy and Research Questions}

The New Educational Models or Paradigms (Salmi, 2011; Salmi et al., 2012), the NEMP-tool, was utilised to obtain feedback from the participants for the measurement of the impact of outdoor pedagogy. This tool does the following: 1) it describes the most typical features of the role of the Outdoor Education itself, 2) it shows the actual changes in learning environment and 3) it defines innovative learning approaches. It contains 27 items on a 5-step Likert-scale (see the chapter "Factor analysis"). The research problems were as follows:

1. What are the pedagogical benefits of using Outdoor Education (OE) solutions in biology education for teacher professional development?

2. How does the role of Outdoor Education (OE) in teaching biology differ from the role of using traditional 
classroom applications?

3. How does the tool known as New Educational Models or Paradigms (NEMP), which was originally developed for ICT-education research purposes, and is here used in the modified version, fit for the research of Outdoor Education (OE) among the teachers and teacher trainees?

\subsection{The Study Design of the Role of Outdoor Education: Research-Based Teacher Education}

The data was collected among teacher trainees of the University of Helsinki. The questionnaire was completed a week after the intensive obligatory course for all the second-year students, which included both theoretical lectures and literature, as well as the outdoor education in the near-by park, forest and natural environment (see the detailed description of this course in the previous section).

The questionnaires were administrated in connection with the courses held in September 2010 and 2011. The total number of subjects was 194 teacher trainees $(2010 N=119 ; 2011 N=75)$. The NEMP-questionnaire was completed as an e-version via the Internet as a routine part of the feedback and evaluation of the course. The students were experienced in using the web-based questionnaire tool from their earlier studies and courses. The background data registered for the subjects included age, gender, educational background and work experience. Many of them had also been working as classroom, primary school, high school or kindergarten teachers for some period either before or during their studies.

\subsection{Factor Analysis}

The main hypothesis for the factor analysis was that the answers to 27 items would be loaded for the three clear factors identified as follows: a) "The role of the method", b) "Changes in the learning environments" and c) "The innovative approaches". Because of the strong presumptions based on the testing of the theory, model and tool, the factor analysis was mainly confirmative in character. However, the research method factor analysis also contained certain explorative elements, since a strict formulated hypothesis was not formulated before the statistical tests. Factor analysis was done based on a correlation matrix.

The factor analysis was carried out using the maximum likelihood method. First, attention was paid to the correlation matrixes of the items. The matrix did not contain any borderline, high-valued correlations; in other words, multicollinearity or singularity did not cause any problems for the main analysis.

The factor matrix was rotated using the Varimax method. As the items in both the NEPM theory and practice in the factor analysis exhibited mutual correlation, it would have been possible to utilize Promax rotation. However, this method did not produce any additional value or clearer results: the "Role" and "Innovative" factors would have correlated and become slightly blended if the Promax rotation had been used.

\section{Results}

As a result of the factor analysis, three clear factors were formed from the 27 separate items (see Table 1). This main result strongly supported the theory behind the model. The main theoretical interest in this result lays in the fact that the NEPM theory was originally developed to structure ICT-based education.

The factors were loaded in a relevant statistical way. According to the background theory the three factors are named as: 1) Role of outdoor education, 2) Changes in learning environments and 3) Innovative approaches, as shown in the previous table.

Only three variables were excluded from the original data, because they did not totally fit into the final factor structure. Thus, there were 24 variables left forming a strong entity. Each of these three items (number 4, 12 and 26) represented different factors, and their exclusion still kept the original "slice model" in balance.

In Table 1, only factors with a loading above .3 are included. Thus, the following three items were excluded from the final analysis:

Factor 1: Role of outdoor education: item 4: "OE as Instruction tool",

Factor 2: Learning Environment: item 12: "OE as Technological innovation",

Factor 3: Innovative Approach: item 26: "SCE Multi-disciplinary knowledge".

The factors (1) "Role" and (3) "Innovativeness" had a strong correlation, as is shown in Table 2.

The only element which at first caused confusion was the clear link between factors 1 and 3 . The correlation between these factors showed high values $(r=0.155, p<0.092)$. 
Table 1. Factor analysis of outdoor education (OE) based on the NEPM theory.

\begin{tabular}{|c|c|c|c|c|}
\hline & Outdoor education & Factor & & \\
\hline & & Role & Changes & Innovativeness \\
\hline & & 1 & 2 & 3 \\
\hline \multirow{9}{*}{ The role of outdoor education } & 1. $\mathrm{OE}$ as connection between learning environments & 0.561 & & \\
\hline & 2. OE as market place & 0.625 & & \\
\hline & 3. OE as communication forum & 0.488 & & \\
\hline & 5. OE as provider of feedback & 0.300 & & \\
\hline & 6. $\mathrm{OE}$ as framework & 0.430 & & \\
\hline & 7. $\mathrm{OE}$ as simulator & 0.496 & & \\
\hline & 8. $\mathrm{OE}$ as tool & 0.609 & & \\
\hline & 9. OE as information bank & 0.696 & & \\
\hline & 10. OE as shared material & 0.474 & & \\
\hline \multirow{7}{*}{$\begin{array}{l}\text { Changes in the learning } \\
\text { environmentin outdoor } \\
\text { education }\end{array}$} & 11. OE as media & 0.388 & & 0.316 \\
\hline & 13. OE Organisational changes & & 0.516 & \\
\hline & 14. OE Pedagogical changes & & 0.657 & \\
\hline & 15. OE Cultural changes & & 0.464 & \\
\hline & $\begin{array}{l}\text { 16. OE Changes in roles and responsibilities of } \\
\text { teachers }\end{array}$ & & 0.561 & \\
\hline & 17. OE Changes in roles and responsibilities of pupils & & 0.521 & \\
\hline & 18. OE New physical spaces & & 0.549 & \\
\hline \multirow{8}{*}{$\begin{array}{l}\text { Innovativeness of outdoor } \\
\text { education }\end{array}$} & 19. OE From instruction to self instruction & & & 0.333 \\
\hline & 20. OE Learning as social participation & & & 0.618 \\
\hline & $\begin{array}{l}\text { 21. OE Differentiated learning depending on different } \\
\text { ways of perception }\end{array}$ & & & 0.434 \\
\hline & $\begin{array}{l}\text { 22. OE From teacher-controlled learning to pupil } \\
\text { controlled learning }\end{array}$ & & & 0.457 \\
\hline & 23. OE Distributed learning & & & 0.636 \\
\hline & 24. OE Collaborative models & & & 0.603 \\
\hline & 25. OE Context-related knowledge & 0.540 & & 0.305 \\
\hline & $\begin{array}{l}\text { 27. OE Integration of other learning environments } \\
\text { than the school }\end{array}$ & 0.346 & & 0.314 \\
\hline
\end{tabular}

Table 2. Correlations between the factors.

\begin{tabular}{|c|c|c|c|c|}
\hline Outdoor education & & Factor1 Role & Factor 2 Change & Factor 3 Innovativeness \\
\hline \multirow{2}{*}{ Factor 1: Role } & cor & 1 & -0.005 & 0.155 \\
\hline & $\mathrm{p}=$ & & 0.954 & 0.092 \\
\hline \multirow{2}{*}{ Factor 2: Change } & cor & -0.005 & 1 & -0.005 \\
\hline & $\mathrm{p}=$ & 0.954 & & 0.956 \\
\hline \multirow{2}{*}{ Factor 3:Innova } & cor & 0.155 & -0.005 & 1 \\
\hline & $\mathrm{p}=$ & 0.092 & 0.956 & \\
\hline
\end{tabular}

\subsection{Background Variables}

For the background variables (gender, age, work experience, educational level) and for the further analysis, factor points were calculated for all $(N=194)$ the subjects. Due to the design of this study, the factors may correlate with each other. This gives the opportunity to use regression as an additional research method. The background variables have been viewed based on these factor points. Single items have been taken into account only if special control data has been demanded. 
The size of the sample and number of subjects is large enough, and the number of subjects in the sub-groups is adequate. However, the sizes of the sub-groups were not homogenous. That is because some of the sub-groups were united to create big enough groups. In the post hoc tests, the Hochbergin GT2 method was utilised to take into account and prohibit the probable effect caused by the different sizes of the sub-groups.

\subsection{Gender}

The answers of both genders to the 27 items indicated similar feedback and reactions. Female teacher trainees had a slightly more positive view of the possibilities of outdoor education as a teaching method. However, the difference was not statistically significant in relation to any of the three factors.

\subsection{Work Experience}

The age of the teacher trainees varied between 19 to 37 years. This is because in Finland some students do not start their teacher studies immediately after graduation from upper secondary school. Some students also stop their studies after 2 - 3 years and start to work in the school or elsewhere and then come back to university to finalise their studies at a later date. This means that the work experience differs between the teacher trainees, and they are not a homogenous group in this sense. The work experience was classified into three groups: 1) no experience, 2) 1 year or less and 3) more than 1 year.

There were no statistically significant differences between the groups in relation to the changes in learning environments or innovative approaches. However, the answers related to the factor Role of Outdoor Education clearly differed according to work experience in the school system: the longer the teachers had been working in the classroom, the higher the value they gave to the variables included in this factor. The difference between the groups no school work experience and more than 1 year school work experience was statistically significant ( $p$ $=.002$ ). The group more than 1 year experience was aggregated from two sub-groups. Inside this group, a similar trend was also found: the longer work experience the subject had, the higher value the person gave to the factor Role of Outdoor Education.

\subsection{Age}

The results of the different age groups confirm the outcomes of the evaluation of the effect of work experience. In addition, it is most probable that the oldest persons also had the longest work experience. The results of these two background variables were identical. The difference between the youngest and oldest age groups was statistically significant $(p<0.001)$.

There were three items that correlated most with age and work experience: Outdoor Education as knowledge market place (2), Outdoor Education as communication forum (3) and Outdoor Education as Information bank (9). In addition, the difference related to age was also statistically significant inside the items Outdoor Education as provider of feedback (5) and Outdoor Education as tool (8). However, this was not the case in relation to the other factors of Changes in learning environments and Innovative approaches.

\section{Validity and Reliability}

The data gathering proceeded very fluently for this research. In practice, the great majority $(N=194)$ of the teacher trainees in the second year cohorts in 2010 and 2011 at the University of Helsinki attended the course and completed the e-questionnaire as part of the evaluation and further development of the obligatory course. In practice, loss and non-response (9\%) was low, and thus the data covered nearly the entire population.

Opinions related to sample size and the number of subjects in relation to the number of items have varied in the research literature recently. According to Field's (2009: pp. 645-647) metadata from several researchers, the number of the subjects should be 5 to 15 times larger than the number of items. In this study, there are approximately nine subjects for each of the items.

In the factor analysis method, the number of subjects is also linked with the strength of the factor loadings and the size of the communalities. These numeric values are fairly low, and the mean numeric value of the communalities included in the data after the rotation is 0.382 .

However, the factor loadings turned out to be reasonably strong. One-half of the items were above the numeric value 0.5 , and seven items even reached the level of 0.6. The Kaiser-Meyer-Olkin (KMO) measure of 
sampling adequacy is an index used to examine the appropriateness of factor analysis, and it takes into account the communalities in relation to the number of subjects. The $K M O$ value in this study was 0.774 . According to the methodology review (Field, 2009: p. 647), a level of around 0.80 is considered good. This indicates that there is enough deviation and heterogeneity in the data to make the factor analysis successful.

Cronbach's Alpha method was utilised as a measurement for internal reliability. Recently, there has been growing criticism of the Alpha, mainly because it describes only one-dimensional data (Cohen, Manion \& Morrison, 2011). Thus, in this study Cronbach's Alpha has been calculated separately for each of the factors in addition to the whole data (see Table 3).

The three factors were also tested using the Kolmogorov-Smirnovin test and proved to be based on normal distribution data.

In the methodology, the critical value for Cronbach's Alpha is considered to be above the 0.7 level. As the results of Table 3 show, all the items and variables turned out to be reliable in this study.

In addition, the correlations between the variables turned out to be suitable. Nearly all the correlations among the variables included in each of the three factors were between 0.2 and 0.6. These values fulfil the Tabanik-Fidell criteria for valid and reliable factor analysis. In addition, the correlations are not so high as to be at risk of multicollinearity.

The variables have been pre-tested and measured using an existing ordinal scale. The variables and items were also divided according to the normal distribution. The data did not contain any outliers or observations crucially distant from the rest of the data.

The traditional way of evaluating the reliability is the split-half method. In this case, a practical way of viewing the data was to analyse the data from the years 2010 and 2011 separately.

All the items of the factor analysis were crosschecked using the independent samples t-test. Only one item showed statistically significant difference, which is most probably only because of random variation while operating on the risk level $p<0.05$ (The item was number 13, Organisational changes).

The factor analysis of the entire data (years 2010 and 2011) also produced very similar results to the 2011 data alone. All three factors (Role, Environment, Innovativeness) were loaded according to exactly the same schema and values. The items excluded were also nearly identical: in the original data the variables rejected were 12 , 25,26 , and in the united data they were $4,12,26$.

The results related to the age of the subjects were the most interesting. However, the distribution of the age groups was within a narrow range: under 22 years old, 23 to 30 years old and over 30 years old. The outcome related to age was so clear that it indicates that the older, in-service teachers should be the target audience of further study of the NEMP-model.

ANOVA-tests are not totally robust and immune to data that is not formed according to the normal distribution (Field, 2009: pp. 359-360, 559). In the items in our data, positive answers dominated in some variables, causing the forms of distributions to be skewed to the left. To avoid any wrong, unreliable interpretations, the results produced by the ANOVA-tests have been double-checked using non-parametric tests (Clark-Carter, 2010). As a replacement of the t-test, the Kolmogorov-Smirnov Z-test was utilised when evaluating the age group differences (Field, 2009: p. 548). In addition, ANOVA-tests were filtered through the Jonckheere-Terpstatest, because there was a presumption that the trends within the groups would grow systematically (Field, 2009: p. 568). In summary, the non-parametric tests produced identical answers to the demanding matching methods of the original tests.

\section{Discussion}

How does the tool known as New Educational Models or Paradigms, originally developed for ICT-education research purposes, and here used in a modified version, fit for the research of Outdoor Education (OE) for the

Table 3. Cronbach's alpha separately for all variables and the three factors of outdoor education (OE).

\begin{tabular}{ccccc}
\hline & $\begin{array}{c}\text { Outdoor education all } \\
\text { variables }\end{array}$ & $\begin{array}{c}\text { The role of outdoor } \\
\text { education }\end{array}$ & $\begin{array}{c}\text { Change in the learning environment in } \\
\text { outdoor education }\end{array}$ & $\begin{array}{c}\text { Innovativeness of the outdoor } \\
\text { education }\end{array}$ \\
\hline $\begin{array}{c}\text { Cronbach's } \\
\text { Alpha }\end{array}$ & 0.827 & 0.799 & 0.714 & 0.749 \\
$N=\begin{array}{c}\text { number of } \\
\text { items }\end{array}$ & 24 & 10 & 6 & 8 \\
\hline
\end{tabular}


teacher professional development? The empirical results of this study support the theoretical part of the New Educational Models or Paradigms presented in the paper. The factor analysis and the other outcomes of the data confirm the design of the study. The entity certainly gives new evidence for the development of outdoor education.

The data was collected during two different autumns. This gave an opportunity to view the data according to the split-half method. Theoretically, for several reasons, there was no motivation to hold the presumption that the results would be different: 1) the students were selected for university using the same type of tests and examinations, 2) the official content of the course has remained the same and 3) the lecturer in charge of the outdoor education did not change. The empirical data supported the hypothesis. There was no difference between the results in the data collected in 2010 and 2011.

Even the items excluded from the factor analysis provide new thoughts for the further development of the NEMP theory. Items number 4 ("instruction tool”), 12 ("technological innovation") and 26 ("Multi-disciplinary approaches”) were excluded from the factor analysis as reported in the Results chapter. These variables were left out of the factor analysis because they did not correlate with their own factor. Otherwise, the following items were eligible: variance was high enough, and the form (skewness: kurtosis) reached above average-level values. Items number 4 and 12 did not correlate with the variables they should have, and conversely, item 26 did correlate with practically all of the items. This is the mathematical and statistical explanation for excluding these three items.

What are the pedagogical benefits of using Outdoor Education (OE) applications in teaching biology at school? The items excluded from the factor analysis provide new thoughts for the further development of the NEMP theory. First of all, the fact that the item Multi-disciplinary approaches correlated with nearly all other items indicates that outdoor education is very integrative by nature. It combines several topics, such as biology, geography, geology and environmental education. Outdoor education also seems to have a very holistic nature; it captures the students' imagination and engages them immediately in real action. There is no essential need for 'instruction tool', as represented by item 4 . Outdoor education also takes place in nature, and the item technological innovation might sound irrelevant and out-of context.

The differences related to age and schoolwork experience gave certain indications. Teachers with more practical classroom experience clearly see more options to break routines by using the new alternatives and challenges offered by outdoor education. As was reported earlier in the Results section, these differences turned up especially in the context of the items Knowledge market place, Communication forum and Information bank. Those teachers with more experience, and perhaps also with more self-confidence, felt that outdoor education contains knowledge-based elements which do not exist in the classroom environment, in text books or in audiovisual or ICT-materials.

There was also a statistically significant difference related to age and work experience in regard to the items Outdoor education as provider of feedback and Outdoor education as tool. It seems that real work as a teacher gives more vision about how to apply outdoor education solutions.

\section{Conclusions}

The results strongly support the vision of utilising short-term PD-efforts (Lauer, Christopher, Firpo-Triplet, \& Buchting, 2014) instead or side-by-side with long lasting courses (Guskey \& Yoon, 2009). The results of this study encourage the use of intervention type activities in teacher professional development.

The results contain clear hints that the study should be repeated among teachers in in-service training. This might provide new evidence for the practice of outdoor education and strengthen the methods of the NEMP approach that came out of this study, thus making it a reliable tool and valid theory.

In Finland, the new trend (National Board of Education, 2015) underlines interactive teaching environments and learning out of school as a resource for teaching. Learning should be multifaceted and combined to place and time. Besides the traditional subject orientated teaching the curricula give guidelines about how to use an approach called "phenomenon based learning".

How does the role of Outdoor Education (OE) in teaching biology at school differ from the role of using traditional classroom applications? Environmental problems such as the loss of habitats and biodiversity, climate change and all the other environmental challenges will have to be faced by everyone today and in the future (Hanski, 2011; Harley, 2011). 


\section{References}

Ahtee, M., Suomela, L., Juuti, K., Lampiselkä, J., \& Lavonen, J. (2009). Primary School Student Teachers’ Views about Making Observations. NorDiNa, 5, 128-141.

Ballantyne, R., \& Packer, J. (2002). Nature-Based Excursions: School Students’ Perceptions of Learning in Natural Environments. International Research in Geographical and Environmental Education, 11, 218-236. http://dx.doi.org/10.1080/10382040208667488

Baram-Tsabari, A., \& Segev, E. (2011). Exploring New Web-Based Tools to Identify Public Interest in Science. Public Understanding of Science, 20, 130-143. http://dx.doi.org/10.1177/0963662509346496

Barker, S., Slingsby, D., \& Tilling, S. (2002). Teaching Biology outside the Classroom. Is It Heading for Extinction? A Report on Biology Fieldwork in the 14-19 Curriculum. British Ecological Society.

Bilton, H. (2010). Outdoor Learning in the Early Years. Management and Innovation (3rd Edition). New York: Routledge.

Bitgood, S. (1988). A Comparison of Formal and Informal Learning. Technical Report 88-10. Jacksonville, AL: Center for Social Design.

Bogner, F. X. (1998). The Influence of Short-Term Outdoor Ecology Education on Long-Term Variables of Environmental Perspective. Journal of Environmental Education, 29, 17-29. http://dx.doi.org/10.1080/00958969809599124

Bogner, F. X., \& Wiseman, M. (2004). Outdoor Ecology Education and Pupils' Environmental Perception in Preservation and Utilization. Science Education International, 15, 27-48.

Braund, M., \& Reiss, M. (2007). Towards a More Authentic Science Curriculum: The Contribution of Out-of-School Learning. International Journal of Science Education, 28, 1373-1388. http://dx.doi.org/10.1080/09500690500498419

Catling, S. (1998). Geography in the National Curriculum and beyond. In Carter, R. (Eds.), Handbook of Primary Geography (pp. 29-41). Hong Kong: Colorcraft Limited.

Cavas, B. (2011). Outdoor Education in Natural Life Park: An Experience from Turkey. Science Education International, 22, 152-160.

Chawla, L., \& Flanders, D. (2007). Educating for Strategic Environmental Behavior. Environmental Education Research, 13, 437-452. http://dx.doi.org/10.1080/13504620701581539

Clark-Carter, D. (2010). Quantitative Psychological Research: The Complete Student's Companion. Sussex: Psychology Press-Taylor \& Francis.

Cohen, L., Manion, L., \& Morrison, K. (2011). Research Methods in Education (7th ed.). London: Routledge.

Crane, V., Nicholson, H., Chen, M., \& Bitgood, S. (1994). Informal Science Learning. Dedham, MA: Research Communications.

D’Amato, L. G., \& Krasny, M. E. (2011). Outdoor Adventure Education: Applying Transformative Learning Theory to Understanding Instrumental Learning and Personal Growth in Environmental Education. The Journal of Environmental Education, 42, 237-254. http://dx.doi.org/10.1080/00958964.2011.581313

Deci, E., \& Ryan, R. (2007). SDT-Theory. http://www.psych.rochester.edu/SDT/

Dierking, L. D., \& Falk, J. H. (1997). School Field Trips: Assessing Their Long-Term Impact. Curator, 40, 211-218. http://dx.doi.org/10.1111/j.2151-6952.1997.tb01304.X

Dillon, J., Rickinson, M., Teamey, K., Morris, M., Young Choi, M., Sanders, D., \& Benefield, P. (2006). The Value of Outdoor Learning: Evidence from Research in the UK and Elsewhere. School Science Review, 87, 107-111.

Dye, V., Herrington, M., Hughes, J., Kendall, A., Lacey, C., \& Smith, R. (2010). Collaborative Writing and Dis-Continuing Professional Development: Challenging the Rituals and Rules of the Education Game? Professional Development in Education, 36, 289-306. http://dx.doi.org/10.1080/19415250903457497

Eaton, D. (1998). Cognitive and Affective Learning in Outdoor Education. Dissertation, Department of Curriculum, Teaching and Learning, Toronto: University of Toronto.

Erdogan, M., Erentay, N., Barss, M., \& Nechita, A. (2008).Students’Awareness of Endangered Species and Threatened Environments: A Comparative Case-Study. International Journal on Hands-on Science, 1, 1-8.

Falk, J. (1982). Environmental Education: Formal vs. Informal Learning. Environmental Education and Information, 2, 171178.

Falk, J. (2005). Free-Choice Environmental Learning: Framing the Discussion. Environmental Education research, 13, 437452. http://dx.doi.org/10.1080/13504620500081129

Fenichel, M., \& Scheingruber, H. (2010). Surrounded by Science. Washington DC: The National Academies Press.

Fenyvesi, K., Koskimaa, R., \& Lavicza, Z. (2015). Experiential Education of Mathematics: Art and Games for Digital Natives. Kasvatus \& Aika, 9, 107-134. 
Field, A. (2009). Discovering Statistics Using SPSS. London: SAGE Publications.

Frantz-Pittner, A., Grabner, S., \& Bachmann, G. (2011). Science Center Didaktik. Hohengehren: Schneider Verlag.

Gafoor, K. A., \& Smitha, N. (2012). Out-of-School Experience Categories Influencing Interest in Science of Upper Primary Students by Gender and Locale: Exploration on an INDIAN Sample. Science Education International, 23, 191-204.

Gardner, H. (1991). The Unschooled Mind. How Children Think and How Schools Should Teach. New York: Basic Books.

Goldschmidt, M., \& Bogner, F. (2015). Learning about Genetic Engineering in an Outreach Laboratory: Influence of Motivation and Gender on Students' Cognitive Achievement. International Journal of Science Education, Part B, 6, Advance Online Pub.

Guskey, T. R. (2002). Professional Development and Teacher Change. Teachers and Teaching: Theory and Practice, 8, 381391. http://dx.doi.org/10.1080/135406002100000512

Guskey, T. R., \& Yoon, K. S. (2009). What Works in Professional Development? Phi delta kappan, 90, 495-500. http://dx.doi.org/10.1177/003172170909000709

Hanski, I. (2011). Habitat Loss, the Dynamics of Biodiversity, and a Perspective on Conservation. Ambio, 40, $248-255$. http://dx.doi.org/10.1007/s13280-011-0147-3

Harley, C. D. G. (2011). Climate Change, Keystone Predation, and Biodiversity Loss. Science, 334, 1124-1127. http://dx.doi.org/10.1126/science.1210199

Holbrook, J., \& Rannikmae, M. (2009). The Meaning of Scientific Literacy. International Journal of Environmental and Science Education, 4, 275-288.

Illich, I. (1971). Deschooling Society. New York: Harper and Row.

Jarvis, T., \& Pell, A. (2004).Primary Teachers' Changing Attitudes and Cognition during a Two-Year Science In-Service Programme and Their Effect on Pupils. International Journal of Science Education, 26, 1787-1811. http://dx.doi.org/10.1080/0950069042000243763

Job, D. (1999). New Directions in Geographical Fieldwork. Cambridge: Cambridge University Press.

Kaasinen, A., \& Suomela, L. (2012). Examples of Implementing Outdoor Education. In H. Salmi (Ed.), Implementing Inquiry beyond the School (pp. 12-18). EU: The Fibonacci Project. http://www.fondation-lamap.org/sites/default/files/upload/media/5\%20-\%20implementing_inquiry_beyond_the_school.pdf

Lambert, D., \& Balderstone, D. (2010). Learning to Teach Geography in the Secondary School (2nd ed.). A Companion to School Experience, London: Routledge.

Larson, L. R., Green, G. T., \& Castleberry, S. B. (2009). “I’m too Old to Go Outside!” Examining Age-Related Differences in Children's Environmental Orientations. In C. E. Watts Jr., \& C. L. Fisher (Eds.), Proceedings of the 2009 Northeastern Recreation Research Symposium (pp. 42-46). Gen. Tech. Rep. NRS-P-66. Newtown Square, PA: U.S. Department of Agriculture, Forest Service, Northern Research Station.

Larson, L. R., Green, G. T., \& Castleberry, S. B. (2011). Construction and Validation of an Instrument to Measure Environmental Orientations in a Diverse Group of Children. Environment and Behavior, 43, 72-89. http://dx.doi.org/10.1177/0013916509345212

Lauer, P. A., Christopher, D. E., Firpo-Triplett, R., \& Buchting, F. (2014). The Impact of Short-Term Professional Development on Participant Outcomes: A Review of the Literature. Professional Development in Education, 40, $207-227$. http://dx.doi.org/10.1080/19415257.2013.776619

Lom, E., \& Sullenger, K. (2010). Informal Spaces in Collaborations: Exploring the Edges/Boundaries of Professional Development. Professional Development in Education, 37, 55-74. http://dx.doi.org/10.1080/19415257.2010.489811

Luehmann, A., \& Markowitz, D. (2007). Science Teacher’s Perceived Benefits of an Out-of-School Enrichment Programme: Identity Needs and University Affordances. International Journal of Science Education, 29, 1133-1161. http://dx.doi.org/10.1080/09500690600944429

Melton, A. (1935). Problems of Installation in Museums of Art: Studies in Museum Education. In E. Robinson (Eds.), New Series 1e.Classical Reprint (pp. 4-23). Washington DC: American Association of Museums.

http://dx.doi.org/10.1037/11526-000

National Board of Education (2004). http://www.oph.fi/english

National Board of Education (2015). National Curriculum 2016.

http://www.oph.fi/english/curricula_and_qualifications/basic_education

Neal, P., \& Palmer, J. (1990). Environmental Education in the Primary School. Trowbridge: Dotesios.

Newsom, B., \& Silver, Z. (Eds.) (1978). Art Museum as an Educator: A Collection of Studies as Guides to Practice and Policy. Berkeley: University of California Press. 
Niklasson, L., \& Sandberg, A. (2010). Children and the Outdoor Environment. European Early Childhood Education Research Journal, 18, 485-496. http://dx.doi.org/10.1080/1350293X.2010.525945

Osborne, J. F., \& Dillon, J. (2008). Science Education in Europe. London: Nuffield Foundation.

Özden, M. (2008). Environmental Awareness and Attitudes of Student Teachers: An Empirical Research. International Research in Geographical and Environmental Education, 17, 40-55. http://dx.doi.org/10.2167/irgee227.0

Rennie, L. (2014). Learning Science Outside of School, 120-144. In N. Lederman, \& S. Abell (Eds.), Handbook of Research on Science Education (pp. 120-144). Vol. 2, New York: Routledge.

Rennie, L., Feher, E., Dirking, L., \& Falk, J. (2003). Towards an Agenda for Advancing Research on Science Learning in Out-of-School Settings. Journal of Research in Science Teaching, 40, 112-120. http://dx.doi.org/10.1002/tea.10067

Richardson, P. (1998). Fieldwork. In R. Carter (Eds.), Handbook of Primary Geography (pp. 181-195). Geographical Association, Hong Kong: Colorcraft Limited.

Rickinson, M., Dillon, J., Teamey, K., Morris, M., Choi, M. Y., Sanders, D., \& Benefield, P. (2004). A Review of Research on Outdoor Learning. National Foundation for Educational Research and King's College London.

Salmi, H. (1993). Science Centre Education, Motivation and Learning in Informal Education. Research Report 119, Department of Teacher Education, Helsinki: University of Helsinki.

Salmi, H. (2003). Science Centres as Learning Laboratories. International Journal of Technology Management, 25, 460-476. http://dx.doi.org/10.1504/IJTM.2003.003113

Salmi, H. (2011). Evidence of Bridging the Gap between Formal and Informal Learning through Teacher Education. Reflecting Education, 8, 45-61.

Salmi, H., Kaasinen, A., \& Kallunki, V. (2012). Towards an Open Learning Environment via Augmented Reality (AR): Visualising the Invisible in Science Centres and Schools for Teacher Education. Procedia Social and Behavioral Sciences, 45, 284-295. http://dx.doi.org/10.1016/j.sbspro.2012.06.565

Salmi, H., Vainikainen, M.-P., \& Thuneberg, H. (2015). Mathematical Thinking Skills, Self-Concept and Learning Outcomes of 12-Year-Olds Visiting a Mathematics Science Centre Exhibition in Latvia and Sweden. Journal of Science Communication, 14, 1-19.

Sturm, H., \& Bogner, F. X. (2010). Learning at Workstations in Two Different Environments: A Museum and a Classroom. Studies in Educational Evaluation, 36, 14-19. http://dx.doi.org/10.1016/j.stueduc.2010.09.002

Tal, R. T. (2001). Incorporating Field Trips as Science Learning Environment Enrichment: An Interpretive Study. Learning Environments Research, 4, 25-49. http://dx.doi.org/10.1023/A:1011454625413

Thuneberg, H. (2007). Is a Majority Enough? Psychological Well-Being and Its Relation to Academic and Prosocial Motivation, Self-Regulation and Achievement at School. Research Report 281, Department of Education, Helsinki: Helsinki University Press.

Tran, N. (2011). The Relationship between Students' Connections to Out-of-School Experiences and Factors Associated with Science Learning. International Journal of Science Education, 33, 1625-1651. http://dx.doi.org/10.1080/09500693.2010.516030

Turner, C. (2006). Informal Learning and Its Relevance to the Early Professional Development of Teachers in Secondary Schools in England and Wales. Journal of In-Service Education, 32, 301-319. http://dx.doi.org/10.1080/13674580600841885

Yerkes, R., \& Haras, K. (1997). Outdoor Education and Environmental Responsibility. Charleston, WV: ERIC Digest.

Zoldasova, K., \& Prokop, P. (2006). Education in the Field Influences Children's Ideas and Interest toward Science. Journal of Science Education and Technology, 15, 304-313. http://dx.doi.org/10.1007/s10956-006-9017-3 


\section{Submit or recommend next manuscript to SCIRP and we will provide best service for you:}

Accepting pre-submission inquiries through Email, Facebook, Linkedin, Twitter, etc A wide selection of journals (inclusive of 9 subjects, more than 200 journals)

Providing a 24-hour high-quality service

User-friendly online submission system

Fair and swift peer-review system

Efficient typesetting and proofreading procedure

Display of the result of downloads and visits, as well as the number of cited articles

Maximum dissemination of your research work

Submit your manuscript at: http://papersubmission.scirp.org/ 